\title{
Investigación sobre morteros y sus tratamientos para su restauración en el Retablo del Altar Mayor de la Basílica del Pilar
}

\author{
Mortars and treatments in the restoration of the \\ Altarpiece of the High Altar of the Pilar Basilica
}

Fecha de recepción: 11-VI-99

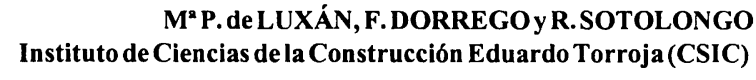

Fecha de aceptación: 29-XI-99

ESPAÑA

\section{RESUMEN}

El retablo de la Asunción de María está situado en el Altar Mayor de la Basílica del Pilar en Zaragoza y es una de las grandes obras del Patrimonio artístico español. La obra, esculpida en alabastro, fue realizada entre 1509 y 1518 por Damian Forment.

En este trabajo se recogen las directrices para el diseño de los morteros de reparación utilizados en la restauración del retablo. Se basaron en criterios de compatibilidad de los materiales y tratamientos existentes en el retablo, según la investigación realizada durante las obras de la última actuación realizada para la limpieza y restauración.

En la investigación realizada se comprobó la composición de los morteros originales, la granulometría de los áridos empleados, así como la composición de los aditivos orgánicos utilizados. Igualmente se analizó e identificó la pátina del retablo.

Los morteros originales estaban compuestos por una mezcla de yeso y cal con adición de aceite o grasa. En muchos casos se detectaron diversos tipos de fibras en la masa de los morteros, utilizadas para mejorar sus características mecánicas.

Los morteros de reparación se han diseñado con una composición similar a la de los antiguos, con una mezcla de yeso y cal, y se estudió su compatibilidad con el alabastro, optimizándose igualmente la granulometría de los áridos a utilizar

\section{SUMMARY}

The altarpiece of the Assumption of Mary is located in the High Altar of the Pilar Basilica in Zaragoza and is one of the most important works of the Spanish Artistic Heritage. The work, sculptured in alabaster, was carried out between 1509 and 1518 by Damian Forment.

The present paper covers the guidelines for the design of repair mortars used to restore the altarpiece. They are based on compatibility criteria with the existing materials and treatments in the altarpiece, according to research carried out during the recent works of cleaning and restoration.

During the previous research, the composition of the original mortars was tested, the aggregate granulometry, and the composition of the organic additives used. The patina of the altarpiece was also analyzed and identified.

The original mortars were made up of a mixture of gypsum and lime with the addition of oil or fats. In many cases various types of fibre were detected in the mortar, used to improve its mechanical characteristics.

The repair mortars were designed with a composition similar to the originals, with a mixture of gypsum and lime, and their compatibility with the alabaster was studied, while also optimizing the granulometry of the aggregates used. 


\section{DATOS HISTÓRICOS}

La actual Basílica de El Pilar está erigida en el mismo lugar donde, según la tradición, el apóstol Santiago construyera una modesta capilla tras el excepcional suceso de la aparición de la Virgen que recibió el nombre de Santa María La Mayor. Desde aquel entonces el edificio sufrió numerosos avatares y en las contiendas contra los sarracenos quedó prácticamente destruido, como así se expresa en un documento de 1118 (1). Tras la reconquista se levantó de nuevo y su fábrica perduró hasta finales del siglo XVII, y poseía, entre sus obras de arte, el Retablo. En 1681 se puso la primera piedra del gran edificio que hoy constituye la Basílica, mas el Retablo permaneció en su lugar de origen hasta el año 1717, en que fue trasladado a su actual ubicación (2)

El Retablo de la Asunción de Nuestra Señora está situado en el Altar Mayor de la Basílica de El Pilar de Zaragoza, obra del maestro Damián Forment, se concluyó en 1518, por lo que es diez años anterior a su obra análoga ubicada en la catedral de Huesca. Su estilo es gótico flamígero, a excepción del sotobanco que posee carácter renacentista. Esculpido totalmente en alabastro, mide, según estudios recientes, $16,75 \times 9,70 \mathrm{~m}(2)$.

En marzo de 1993 se inició el último proyecto general de intervención que culminó en julio de 1994. En él se abordaba una limpieza y restauración general con el fin de devolver a la obra todo su esplendor, y fue llevado a cabo por el Equipo de Restauración coordinado por Mercedes Nuñez y bajo la dirección técnica de Olga Cantos (ICRBC).

Desde su traslado a la Basílica el Retablo ha sido objeto de diversas actuaciones, así, se observan antiguos anclajes metálicos de plomo; en 1928 se constata un refuerzo de los pilares; durante los años 60 se efectuaron reparaciones con mortero de cemento y, en los años 70 , se aplicó un tratamiento y protección superficial en toda la obra (2).

La restauración del Retablo del Pilar se ha desarrollado con la colaboración del Instituto E. Torroja en la investigación sobre los materiales, los morteros y los tratamientos, tomando, como punto de partida, los existentes en el propio monumento. Mediante su caracterización se han establecido las pautas para el diseño de los morteros aplicables en la restauración, en el transcurso de la intervención. Este trabajo aborda los aspectos generales de dicho estudio llevado a cabo durante la restauración.

Antecedente de esta investigación y con notables aspectos conexos es la realizada en la Portada de alabastro de la también zaragozana Iglesia de Santa Engracia (3).

\section{HISTORICAL DATA}

The present Basilica of El Pilar is built on the site where, according to tradition, Saint James the Apostle built a modest chapel following the miraculous appearance of the Virgin, and which received the name of Santa Maria La Mayor. Following that time, the building suffered numerous transformations and during the wars against the Sarracins was practically destroyed, as mentioned in a document of 1118 (1). Following the Reconquest it was rebuilt and the construction endured until the end of the $X V I I$ century, including the Altarpiece among its works of art. In 1681 the first stone was laid of the great building that today forms the Basilica, with the Altarpiece

remaining in its original position until 1717, when it was moved to its present location (2).

The Altarpiece of the Assumption of Our Lady is located on the High Altar of the Basilica of El Pilar in Zaragoza, work of the master Damian Forment and finished in 1518, which makes it ten years prior to a similar work by him found in the cathedral of Huesca. The style is Flemish Gothic except for the socle which is in the Renaissance style. Sculptured completely in alabaster, according to recent studies it measures $16.75 \times 9.70 \mathrm{~m}$ (2).

In march 1993 the last general works program was begun which was finished in july 1994. During this, cleaning and general restoration was undertaken to restore the work to its original splendour, carried out by the Restoration Team co-ordinated by Mercedes Nuñez and under the technical direction of Olga Cantos (ICRBC).

Since its removal to the Basilica, the Altarpiece has suffered various actions, and old metal attachments of lead can be seen; in 1928 the pillars were reinforced; during the sixties repairs were carried out with cement mortar; and in the seventies surface treatment and protection was applied to the whole work (2).

The restoration of the El Pilar Altarpiece has been carried out in collaboration with the E. Torroja Scientific Institute for the investigation of materials, mortars and treatments, taking as a starting point those existing in the monument itself. By characterizing these, during the course of the work the guidelines were established for the design of the mortars to be applied in the restoration. This work covers the general aspects of the study carried out during the restoration.

Prior to this research, and with a notable relationship to the same, was that carried out on the alabaster façade of the Church of Santa Engracia, also in Zaragoza (3). 
El traslado del Retablo en 1717 a su actual emplazamiento, realizado en un breve plazo de tiempo y la necesidad de adaptación al nuevo espacio físico han dado lugar a la mayoría de los defectos de montaje y daños que presenta en la actualidad. Los bloques de alabastro no se encajaron exactamente, esta deficitaria adaptación ha dado lugar a una gran diversidad en la anchura de las juntas y a desplazamientos en los planos vertical y horizontal, se produjeron, al mismo tiempo, pérdidas de material, fisuras y grietas y falta de unión de las piezas con el mortero. El mortero se aplicó en ocasiones en las juntas, sobrepasando su anchura y ocultando parte de la talla.

Los factores externos como la humedad, cambios de temperatura y contaminación, han sido también causa de deterioro del alabastro y de los morteros de junta del Retablo. Las específicas características de la piedra y de los morteros, ambos compuestos mayoritariamente de yeso, hacen que entre ellos sea el agua (humedad) el principal factor de degradación del Retablo, ya que otros contaminantes como el $\mathrm{SO}_{2}$ no afectan fundamentalmente, en este caso, su integridad.

\section{INVESTIGACIÓN DE LOS MATERIALES ANTIGUOS DEL RETABLO}

Los morteros que se pueden considerar originales en el Retablo, al menos desde su ubicación actual, tienen tres funciones principales:

. Unión de cada una de las piezas de alabastro que constituyen los grupos escultóricos.

- Sujeción y asentamiento del conjunto del Retablo para su colocación y ubicación en el interior del edificio, formando parte del mortero de agarre.

- Reintegración de algunos elementos de la piedra de alabastro.

A través del tiempo se han realizado algunas reparaciones con aplicación de nuevos morteros. Anteriores a la actual restauración, se han podido detectar morteros de reparación en las uniones para el rejuntado de piezas desprendidas, en las partes más externas de los morteros de junta, en retallados de algunas piezas singulares y en el relleno de fisuras y grietas producidas en distintas zonas del conjunto escultórico.

Con el primer examen sobre el estado de conservación del Retablo y de los morteros existentes, se establecieron los criterios para realizar una toma de muestras que permitiera la caracterización diferenciada de los morteros. El muestreo se apoyó en la amplia documentación gráfica de una publicación de
The removal of the Altarpiece in 1717 to its present location, carried out in a short space of time, and the need to adapt it to the new physical space, gave rise to the majority of the defects in mounting and the damage seen today. The alabaster blocks do not fit together exactly, and this incorrect adaptation has given rise to great diversity in the width of the joins and the displacements in the vertical and horizontal planes, and at the same time there has been loss of material, fissures and cracks and lack of joining of the parts with the mortar. The mortar was occasionally applied at the joins overlapping their width and hiding part of the sculpture.

External factors such as humidity, temperature changes and pollution, have also caused deterioration to the alabaster and to the joint mortars of the Altarpiece. The specific characteristics of the stone and the mortars, both composed principally of gypsum, means that between them water (humidity) is the main degradation factor in the Altarpiece, since other contaminants, such as $\mathrm{SO}_{2}$, do not affect mainly its integrity in this case.

\section{RESEARCH INTO THE OLD MATERIALS OF THE ALTARPIECE}

The mortars that may be considered as original to the Altarpiece, at least in its present location, have three principal functions:

\section{- Union of each of the pieces of alabaster that form the sculptured groups.}

. Holding and laying of the whole Altarpiece for its placement and location inside the building, forming part of the bonding mortar.

. Reintegration of some alabaster elements.

Over time, various repairs have been carried out with the application of new mortars. Prior to the present restoration, repair mortars have been detected in the joints to repointing the loose pieces in the most external parts of the jointing mortars, in the re-carving of some individual pieces, and in the fill of fissures and cracks appearing in various zones of the overall sculpture.

During a first examination of the state of preservation of the Altarpiece and the existing mortars, the criteria were established for carrying out a sampling that would allow a differentiation between the characteristics of the mortars. The sampling was supported by the extensive graphic 
principios del siglo XX (4), seleccionando con fiabilidad morteros de reparación en grietas y en desprendimientos antiguamente existentes y actualmente renovados, así como también juntas conservadas aún intactas y documentadas fotográficamente en dicha fecha.

Durante las obras de rehabilitación se procedió a desmontar una de las placas de la predela, por lo que se tuvo acceso al mortero de fondo empleado para el asentamiento del Retablo. Su caracterización ha servido como punto de comparación para otros morteros extraídos, para establecer analogías, no para una identificación total, ya que el mortero de agarre ha de tener unas características específicas, especialmente en el contenido y distribución de los tamaños de los áridos. Para la selección de morteros antiguos se han buscado, además, otras zonas interiores de las juntas. Por otra parte, este mortero de fondo proporciona una relación entre el origen y composición de los morteros y su cronología, ya que se puede considerar que su aplicación en obra se efectuó al colocar el Retablo en su nueva ubicación en 1717.

Los morteros estudiados proceden tanto del cuerpo principal como del sotobanco y banco, escogidos en diferentes alturas y profundidades.

El componente mayoritario de los morteros antiguos es el yeso, incluso los áridos están formados principalmente por alabastro. Esta composición proporciona a los morteros originales una tonalidad blanquecina. En todos los casos el aglomerante empleado fue una mezcla de yeso y cal. Esta práctica de incorporar cal al yeso es habitual en la preparación de morteros de yeso tradicionales, ya que la cal mejora las propiedades del yeso, especialmente su trabajabilidad. Los morteros mezcla de yeso y cal reciben el nombre de trabadillos (5).

Esta identificación de la composición mineralógica de los morteros se ha obtenido mediante la aplicación de diversas técnicas instrumentales, obteniendo resultados concordantes (difracción de rayos $\mathrm{X}$, espectroscopía de absorción infrarroja y microscopía electrónica de barrido acoplada al microanálisis por energías dispersivas de rayos X). Incluso la granulometría por rayos láser aplicada al estudio de los aglomerantes de los morteros, además de efectuar el análisis granulométrico, permite detectar la presencia de más de un componente, y así se constata que la finura del yeso empleado como aglomerante es baja.

Como ejemplo se presenta el espectro IR de uno de los morteros estudiados en el que se comprueba la presencia de yeso y carbonato cálcico (Fig. 1). documentation in a publication dating from the beginning of the XX century (4), reliably selecting the repair mortars in the cracks and in the existing old separations now renewed, and also the joints that were still intact and photographically documented at that time.

During the work of rehabilitation one of the plates of the predella was removed to give access to the bonding mortar used to attach the Altarpiece. Its characterization was used as a point of comparison with other mortars extracted, to establish analogies not for total identification, since the holding mortar had to have specific characteristics, particularly in the content and distribution of the sizes of aggregates. Furthermore, to select old mortars we searched in other zones inside the joins. Also, the base mortar offered a relationship between the origin and composition of the mortars and their chronology since it can be considered that they were applied during the work of setting the Altarpiece into its new location in 1717

The studied mortars came from both the main body and the basement, chosen at different heights and depths.

\section{The major component of the ancient mortars is} gypsum, and even the aggregates are formed mainly by alabaster. This composition gives the original mortars a whitish tone. In all cases the binder used was a mixture of gypsum and lime. This practice of incorporating lime with the gypsum is habitual in the preparation of traditional gypsum mortars since the lime improves the properties of the gypsum, particularly its workability. The mortars of a mixture of gypsum and lime receive the name of trabadillos (5).

This identification of the mineralogical composition of the mortars was obtained by the application of various instrumental techniques, obtaining concordant results ( $X$-ray diffraction, infrared absorption spectroscopy and scanning electron microscopy connected to microanalysis by $X$-ray dispersion). The laser granulometry applied to the study of the agglomerates in the mortars, aside from the granulometric analysis, also allowed us to detect the presence of more than one component and it was thus found that the fineness of the gypsum used as agglomerate was low.

As an example, the IR spectrum for one of the mortars studied is given below, in which the presence of gypsum and calcium carbonate can be seen (Fig. 1). 


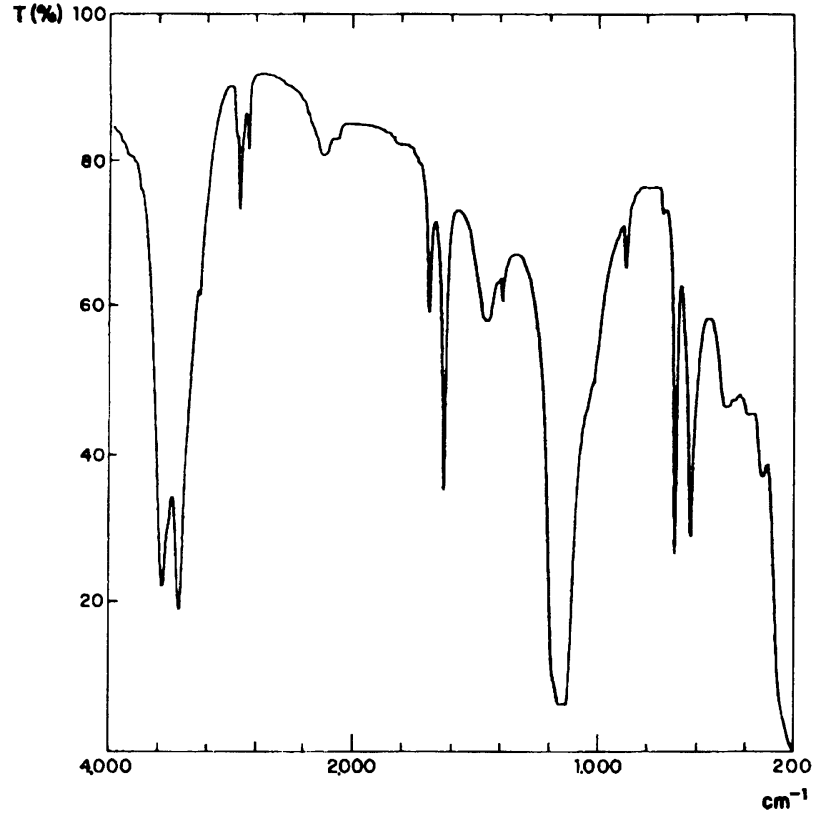

Figura 1.- Composición de un mortero de junta del Retablo de alabastro. Identificación de yeso y carbonato cálcico por espectroscopía IR.

Figure 1.- Composition of a joint mortar from alabaster Altarpiece. Identification of gypsum and calcium carbonate by IR spectroscopy.

Una de las características específicas de los morteros antiguos presentes en el Retablo es la presencia de fibras. Estas fibras evitan la retracción y fisuración de los morteros y le confieren una mayor resistencia mecánica. Su tamaño y proporción dependen de la función del mortero, así por ejemplo en el mortero de fondo hay pequeños fragmentos de madera que llegan a alcanzar hasta casi $1 \mathrm{~cm}$ (Fig. 2). En los morteros de junta el tamaño de las fibras está en relación con el espesor de la junta, aunque lo más frecuente es encontrar fibras de un diámetro entre 0,16 y $0,5 \mathrm{~mm}$ (Fig.3). Junto a estas fibras de origen vegetal es posible apreciar, mediante la microscopía óptica, otras de tonalidad oscura, con apariencia de pelillos y de diámetro muy inferior, en torno a $0,08 \mathrm{~mm}$.

La porosidad de los morteros originales es variable dependiendo del tamaño de los áridos, del contenido de agua empleada en el amasado y de la proporción entre el aglomerante del mortero y los áridos que lo componen. En los morteros de junta se observa una porosidad menor que en el mortero de fondo de sujeción del Retablo, cuyo valor de porosidad accesible alcanzaba un valor del $24 \%$, debido a su mayor proporción de áridos gruesos.

La proporción de finos en los morteros antiguos de junta y de unión es mayor con relación a los gruesos (áridos), en general del orden de 2:1; aunque dada la variación del tamaño de las juntas se encuentran valores

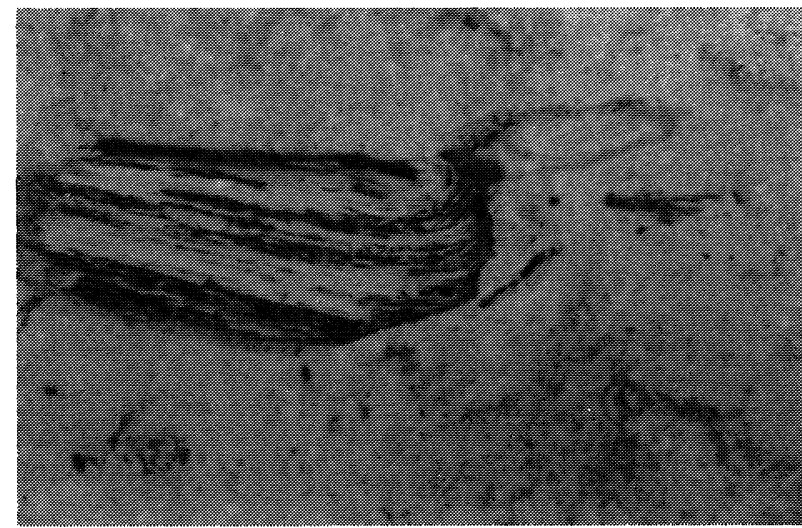

Figura 2.- Fibras de madera del mortero soporte del Retablo (microscopia óptica, $\mathbf{x} 10,7)$.

Figure 2.- Woody fibers in the bottom mortar of the Altarpiece (optical microscopy, $x$ 10.7).

One of the specific characteristics of the old mortars present in the Altarpiece is the presence of fibres. These fibres prevent the retraction and cracking of the mortars and give it greater mechanical resistance. Their size and proportion depend on the function of the mortar, for example the base mortar has small fragments of wood that reach a size of almost $1 \mathrm{~cm}$ (Fig. 2). In the joint mortars the size of the fibres is in relation to the thickness of the joint, although fibres of a diameter between 0.16 and 0.5 mm are most frequently found (Fig. 3). Next to these fibres of vegetable origin others of a dark colour can be seen under an optical microscope, which have the appearance of hairs and with a very much smaller diameter, around $0.08 \mathrm{~mm}$.

The porosity of the original mortars varies depending on the aggregate size, the water content used in the mixing mortar and the binder/aggregate ratio in the mortar. Lower porosity is observed in the joint mortars than in the bonding mortar holding the Altarpiece; where the amount of accessible porosity reaches $24 \%$ due to the greater proportion of coarse aggregates.

The proportion of fines in the old joint mortars is greater in relation to the large particles (aggregates), generally in the order of 2:1; although in view of the variation in size of the joins amounts 


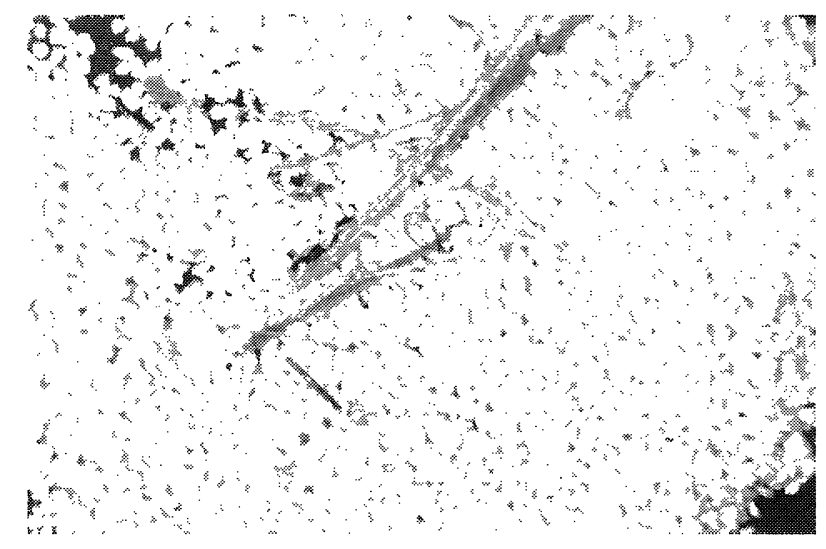

Figura 3.- Pequeñas fibras en un mortero de junta (microscopia ópti$\mathrm{ca}, \mathrm{x} 10,7)$

Figure 3.- Small fibers in a joint mortar (optical microscopy, $x$ 10.7).

hasta de 4:1 o bien en otros casos del orden de 1:1, es decir, con una proporción de finos inferior. En el mortero de fondo el porcentaje de áridos es mayor que el de finos y la proporción aglomerante/áridos es del orden $1: 2$, inversa a la de los morteros de junta.

Respecto a los áridos, su granulometría está directamente relacionada con la función del mortero. Los morteros de junta más frecuentes poseen áridos de tamaños de $0,08 \mathrm{~mm}$, en general los más abundantes, y de $0,16 \mathrm{~mm}$. El mortero de fondo tiene áridos con una distribución completa desde tamaños superiores a 3,36 $\mathrm{mm}$, hasta 7 y $8 \mathrm{~mm}$, a tamaños de $0,08 \mathrm{~mm}$, siendo el tamaño de áridos más abundante el que corresponde a $0,16 \mathrm{~mm}$. Los tamaños de las fibras se ajustan a la granulometría correspondiente de los áridos del mortero.

Las adiciones orgánicas en morteros y pátinas se identificaron mediante espectroscopía de absorción infrarroja, tras extracción con mezclas de disolventes (6). Los morteros antiguos presentan una adición de aceite, muy posiblemente secante, reaccionado en su práctica totalidad. El tipo de adición y el estado de reacción es idéntico al detectado en otros monumentos de España y de Europa.

Antes de la restauración, los morteros existentes se encontraban aparentemente en buen estado de conservación, salvo en lo que a la suciedad superficial se refiere, a la falta de adherencia al alabastro en algunos lugares del conjunto escultórico y a la pérdida de material y fisuraciones ya referidas (Fig. 4)

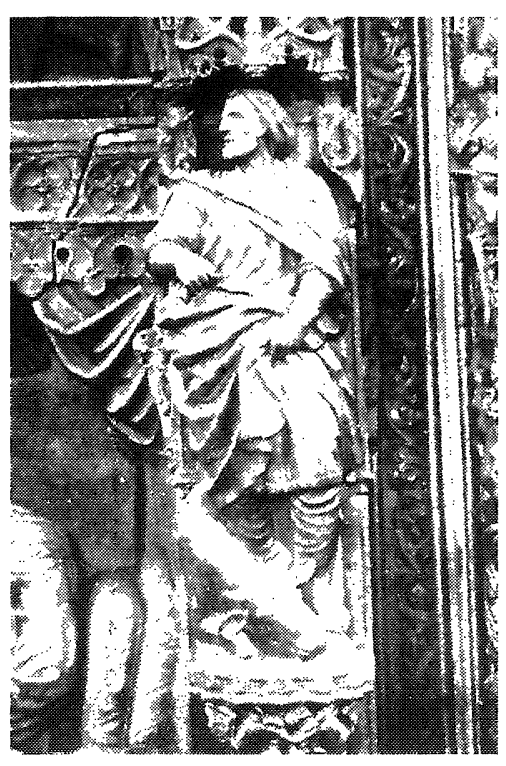

Figura 4.- Cuerpo central del Retablo en 1922. Detalle de roturas antiguas. Imagen de San Marcos en una de las pilastras (3).

Figure 4.- Central zone of the Altarpiece in 1922. Detail of the old cracks Sculpture of san Marcos in a pillar (3).

of up to 4:1 are found while in other cases it is 1:1, i.e. with a lower proportion of fines. In the bonding mortar the percentage of aggregates is greater than fine material and the binder/aggregate ratio is about $1: 2$, the inverse of the joint mortars.

Regarding the aggregates, their granulometry is directly related to the function of the mortar. Joint mortars most frequently have aggregates with sizes of $0.08 \mathrm{~mm}$, generally the most abundant, and of 0.16 $\mathrm{mm}$. The bonding mortar has aggregates with a complete distribution range from sizes of more than $3.36 \mathrm{~mm}$ up to 7 and $8 \mathrm{~mm}$, to sizes of $0.08 \mathrm{~mm}$, with the aggregate size of $0.16 \mathrm{~mm}$ being the most abundant. The fibre size is in accordance with the granulometry corresponding to the aggregates in the mortar.

The organic additives to mortars and patinas were identified by infrared absorption spectroscopy, after extraction with mixtures of solvents (6). The old mortars show the addition of oil, most probably as a dryer, almost all reacted. The type of addition and state of reaction is identical to that detected in other monuments in Spain and Europe.

Prior to the restoration, the existing mortars were apparently in a good state of preservation, except for the surface dirt, the lack of adherence to the alabaster in some parts of the overall sculpture and the loss of material and cracking already mentioned (Fig. 4). 
Los morteros utilizados en el Retablo antes de la presente intervención y que pertenecían a reparaciones anteriores, presentan mayor dispersión de unos a otros en sus características. Sin embargo hay semejanza entre diversos morteros que poseen una misma función de parcheados y remate de juntas, localizados a diferentes alturas en el cuerpo principal e incluso en la predela.

La composición de estos morteros es de yeso y cal, ya en forma de carbonatos, pero a diferencia de los morteros que se han considerado originales, la proporción de cal en este caso es mayor y se detecta un mayor contenido de silicatos en el conjunto del mortero. Su tonalidad en muchos casos es grisácea, sobre todo superficialmente, con apariencia de cemento portland que no han sido objeto de este estudio, y corresponden a intervenciones de los años sesenta (2). Y, finalmente, en algunas reintegraciones se han observado morteros a base de yeso, casi como único componente.

En los tratamientos externos de los morteros estudiados se ha comprobado la existencia de grasas reaccionadas con cal, en mayor o menor proporción, con presencia de ácidos grasos, en general, abundantes. Todas las pátinas son muy posiblemente antiguas, (6) con una sola excepción en la que aparece un jabón bastante reciente y, además, se detecta la presencia de resina (colofonia o pez de colofonia). En los mastiques de base orgánica utilizados como tapagrietas se detectan igualmente aceites y resinas.

Finalmente se realizó el estudio del residuo obtenido en la limpieza del alabastro del Retablo por requerimiento de la restauración. Se comprobó la no detección de acrílicos o similares. En él se verificó la presencia de grasas, resinas y, posiblemente, ceras, reaccionadas con cal en buena parte. La comprobación llevada a cabo mediante TLC (cromatografía en capa fina) (8) confirmó la abundante presencia de jabones y de resinatos.

\section{APLICACIÓN DE RESULTADOS A LA RESTAURACIÓN: LOS MORTEROS DE REPARACIÓN}

Los morteros para la obra de restauración del Retablo se diseñaron en base a las características de los morteros originales, teniendo en cuenta la compatibilidad con los materiales existentes y también las características del alabastro.

Para la ejecución de ensayos de compatibilidad con la piedra en los morteros de reparación, se tallaron

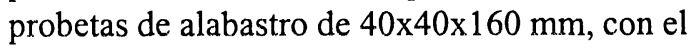

The mortars used in the Altarpiece before the present work, and which belong to later repairs, show greater dispersion of characteristics between each other. However, there are similarities between various mortars that have the same function of patching and completing joints, located at different heights of the main body and even in the predella.

The composition of these mortars is lime, now in the form of carbonates, and gypsum, but differing from the mortars considered as original in that the proportion of lime in this case is greater, and a larger content of silicates is detected in the mortar as a whole. In many cases the colour is greyish, particularly on the surface, with the appearance of portland cement but has not been the object of this study and corresponds to work carried out in the sixties (2). Finally, in some replacements mortars have been found with a gypsum base as almost the sole component.

In the external treatments of the mortars studied, the existence of fats reacted with lime have been found, in greater or lesser proportion, with in general an abundant presence of fatty acids. All the patinas are quite possibly old (6), with the sole exception of the appearance of a fairly recent soap, and also the presence of resin is detected (rosin or rosin pitch). In the organic based mastics used to cover cracks, oils and resins are also detected.

Finally a study was made of the residue obtained from the cleaning of the alabaster of the Altarpiece as required by the restoration. It was found that acrylics or similar were not detected. The presence of fats, resins and, possibly, waxes was found, reacted with lime to a large degree. The tests were carried out by TLC (thin-layer chromatography) (8) and the presence of soaps and resinates was confirmed.

\section{APPLICATION OF THE RESULTS OF THE RESTORATION: THE REPAIR MORTARS}

The mortars for the restoration work on the Altarpiece were designed based on the characteristics of the original mortars, taking into account their compatibility with existing materials and also the characteristics of the alabaster.

To carry out tests for compatibility with the stone in the repair mortars, alabaster test specimens were taken $40 \times 40 \times 160 \mathrm{~mm}$, of material from the quarry 
material procedente de cantera seleccionado para las reparaciones, para efectuar en ellas la evaluación de las propiedades del material pétreo. Se obtuvieron datos sobre el comportamiento mecánico-resistente de la piedra de alabastro a utilizar en la restauración, previamente al diseño de los morteros de reparación, alcanzando los siguientes valores: $10,0 \mathrm{MPa}$ para la resistencia a flexotracción y 24,5 $\mathrm{MPa}$ para compresión.

La composición seleccionada en los morteros para la restauración, en base a los morteros existentes ya en el Retablo, ha sido el yeso, con una adición de cal en baja proporción, para conseguir, de este modo, entre otras ventajas, una mayor plasticidad, de especial importancia en el relleno de juntas finas, una mejora en la trabajabilidad y también en el comportamiento adherente que posee gran interés a la vista de los bajos valores obtenidos en este ensayo con morteros sólo de yeso.

En cuanto a los áridos, la granulometría se mantuvo en torno a mezclas de tamaños entre $0,08 \mathrm{~mm}$ y $0,16 \mathrm{~mm}$, según el espesor de las juntas o los elementos a reparar. En el caso de pequeñas fisuras y reparaciones se suprimieron los tamaños más gruesos. La dosificación de la mezcla a emplear ha sido variable según la aplicación (Figs. 4 y 5).

Para constatar las propiedades del mortero de reparación base, compuesto de yeso, cal y árido fino, y con objeto de seleccionar las proporciones adecuadas se realizaron también ensayos de adherencia entre los morteros y la piedra alabastro, comparando los resultados de la resistencia a la tracción para diferentes tipos de morteros. El equipo empleado fue Instron Universal Testing Instrument, floor model (TT) 1114

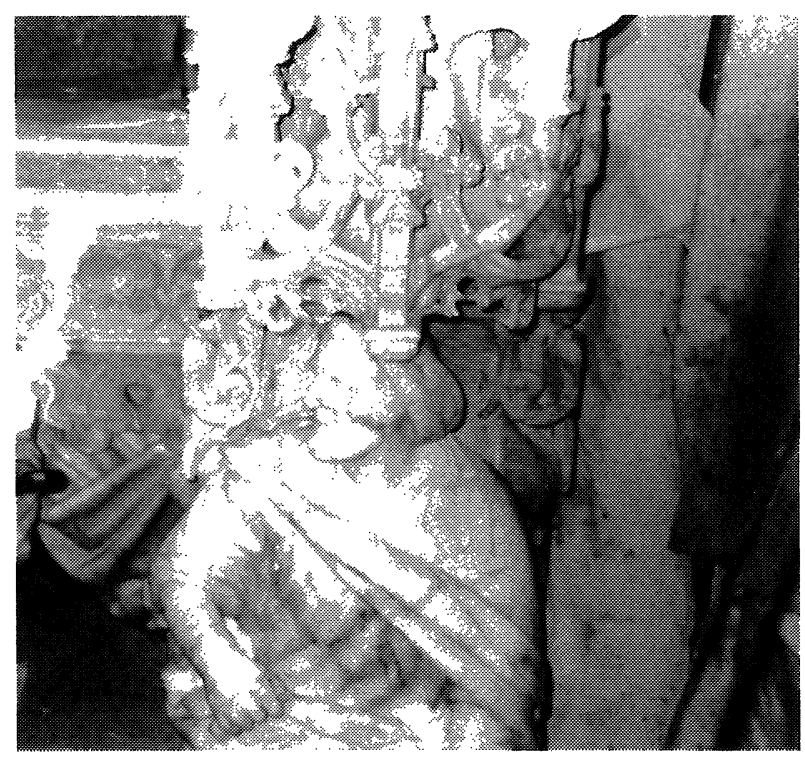

selected for the repairs, to evaluate on them of the properties of the stone material. Data were obtained on mechanical performance of the alabaster stone to be used in the restoration, prior to designing the repair mortars, and reaching the following amounts. 10.0 MPa for flexural and 24.5 MPa for compressive strength.

The selected composition for the restoration mortars, based on mortars already found in the Altarpiece, was gypsum with a low proportion addition of lime to obtain, among other advantages, greater plasticity which was particularly important when filling the fine joints, improved workability and also adherence behaviour which was of great interest in view of the low values obtain in this test with mortars of gypsum only.

Regarding aggregates, granulometry was held at mixtures of sizes between $0.08 \mathrm{~mm}$ and $0.16 \mathrm{~mm}$, according to the thickness of the joints or items to be repaired. In the case of small fissures and repairs the larger sizes were discarded. The dosage of the mixture to be used varied according to the application (Figs. 4 and 5).

In order to define the properties of the base repair mortar, composed of gypsum, lime and fine aggregate, and to select the appropriate proportions, adherence tests were also carried out between the mortars and the alabaster stone, comparing the tensile strength for different types of mortars. The equipment used was an Instron Universal Testing Instrument, floor model (TT) 1114
Figura 5.- Detalle del cuerpo central del Retablo en 1993 durante la restauración. Imagen de San Marcos en una de las pilastras.

Figura 5.- Detail of the central part of the Altarpiece in 1993 during the restoration. Sculpture of San Marcos in a pillar. 
(1175) dotado de un sistema electrónico de pesada, provisto de células de carga y de un sistema de detección para la determinación de la resistencia la tracción y a la compresión de los materiales. Para ensayar los distintos morteros se prepararon cubos de alabastro de $40 \mathrm{~mm}$ de lado, uniéndolos de dos en dos mediante una capa de cada uno de los morteros a ensayar con un espesor medio de $65 \mathrm{~mm}$. Los valores obtenidos con mezclas de yeso y áridos proporcionaron valores muy bajos. Se constató cómo el alabastro empleado como material soporte ofrece, en todos los casos, resultados bajos de adherencia. $\mathrm{Si}$ la proporción de árido en los morteros es menor la adherencia del mortero a la piedra alabastro se incrementa. La zona de rotura en el sistema alabastro + mortero + alabastro se produce en la interfase entre el mortero y la piedra, no provocando, en ningún caso, la rotura de la piedra. Por ello, los morteros, aunque débiles en su adherencia, resguardarán sin daño la piedra labrada de alabastro del Retablo. Eventualmente se podrían utilizar aditivos apropiados para mejorar la adherencia de los morteros.

Para evaluar las características de los morteros en función del tipo de áridos se elaboraron mezclas con diferentes dosificaciones de áridos, que, a su vez, diferían en su composición. Por una parte, se emplearon áridos procedentes de alabastro de machaqueo y se compararon los resultados con arena silícea, resultando que mezclas de yeso (E-35) y árido silíceo (arena normalizada, según norma UNE-EN 196-1), preparadas en la proporción 1:1, arrojaban valores de resistencia mecánica bajos (3,4 MPa para la resistencia a flexotracción y $9,8 \mathrm{MPa}$ para compresión), aunque 4 veces superiores a aquéllas en las que el árido seleccionado era el procedente de piedra alabastro. En cualquier caso las resistencias mecánicas de los morteros preparados eran inferiores a las obtenidas con la piedra alabastro, lo que garantizaba su compatibilidad. Por tanto, la elección de los morteros se efectuó sobre aquéllos que poseían una resistencia a compresión inferior a la que posee la piedra alabastro, con objeto de no dañar, con la reparación, la obra escultórica.

\section{AGRADECIMIENTO}

Los autores agradecen a Olga Cantos y a Ana Laborde, del Instituto de Conservación y Restauración de Bienes Culturales (ICRBC) (Ministerio de Cultura) la participación en el Proyecto, a Mercedes Nuñez su colaboración en el estudio y a la empresa P3, S.A. y Dirección General de Patrimonio del Gobierno de Aragón la financiación de la investigación, así como a la Fundación Nueva Empresa y al Cabildo Metropolitano de Zaragoza.
(1175) with an electronic weighing system, with loading cells and a detection system to determine tensile and compressive strength in the materials. In order to test the various mortars, alabaster cubes 40 $\mathrm{mm}$ long were prepared, joining them two by two using a layer of each one of the mortars to be tested, with an average thickness of $65 \mathrm{~mm}$. The results obtained with mixtures of gypsum and aggregates gave very low amounts. It was found that the alabaster used as support material offered low adherence results in all cases. If the proportion of aggregate in the mortars is lower, the adherence between the mortar and the alabaster stone increases. The fracture zone in the alabaster + mortar + alabaster system occurs in the interface between the mortar and the stone, and in no case led to the failure of the stone. Therefore although their adherence is weak the mortars will hold the carving alabaster stone of the Altarpiece without damaging it. Appropriate additives could be used eventually to improve the adherence of the mortars.

To evaluate the characteristics of the mortars according to the type of aggregates, mixtures were made with different dosages of aggregates which in turn different in composition. On the one hand aggregates were used from crushed alabaster and the results were compared with siliceous sand, with the result that mixtures of gypsum (E-35) and siliceous aggregate (standard sand according to $U N E-E N$ 196-1), prepared in a ratio of 1:1 gave low mechanical strength (3.4 MPa for flexural and 9.8 MPa for compressive strength), although 4 times greater than those in which the aggregate selected came from alabaster stone. In any event the mechanical strength of the prepared mortars was lower than those obtained with alabaster stone, which guaranteed their compatibility. Therefore the choice of mortars was made from those with lower compressive strength than that of alabaster stone, to ensure the restoration did not damage the sculptured work.

\section{ACKNOWLEDGEMENTS}

The authors wish to thank Olga Cantos and Ana Laborde of the Institute for the Preservation and Restoration of Cultural Heritage (ICRBC) (Ministry of Culture) for their participation in the Project, Mercedes Nuñez for her collaboration in the study, and the company P3, S.A. and General Heritage Directorate of the Government of Aragon for financing the research, and also the Nueva Empresa Foundation and Cabildo Metropolitano of Zaragoza. 


\title{
BIBLIOGRAFÍA
}

(1) J. M. Quadrado: "España, sus monumentos y artes - Su naturaleza e historia. Aragón”. Ed. Daniel Cortezo y Cia, Barcelona 1886.

(2) "El Retablo Mayor de la Basílica de Nuestra Señora del Pilar de Zaragoza". Ed. F.Nueva Empresa - Gobierno de Aragón, Zaragoza, 1995.

(3) M.P. Luxán, F. Dorrego, A. Laborde: "Ancient gypsum mortars from Sta Engracia (Zaragoza, Spain): Characterization, identification of additives and treatments". Cement and Concrete Research, vol.25, n.8, 1755-1765, (1995).

(4) A. Magaña: "Zaragoza Monumental". Ed. Artes Gráficas, vol. 2, pp 25-40, Zaragoza 1922

(5) F. Dorrego, M.P. Luxán, R Sotolongo: “Los trabadillos: Origen, utilización y técnicas de preparación”. Ed. CEHOPU - Soc. Ha Constr., pp 145 - 150, Madrid(1998)

(6) F. Dorrego, M.P. Luxán, M. Ruiz: "Reactivity of natural fats with different compounds in historical surface coatings". Surface Coatings International (Journ. Oil Colour Chem), n.2, 70-76,(1994)

(7) C.M. Grossi, R.M. Esbert, F. Díaz-Pache: "Degradación y durabilidad de materiales rocosos de edificación en ambientes urbanos". Materiales de Construcción, 48, 5-15(1998)

(8) M.F. Striegel, D. Stulik: "High perfomance Thin - layer chromatography for the identificaction of binding media. Techniques and applications" Unpublished work belong to The Getty Conservation Institute. 29 pp. Private communication.

\section{Publicación del Instituto Eduardo Torroja - CSIC}

\author{
Número monográfico de INFORMES
}

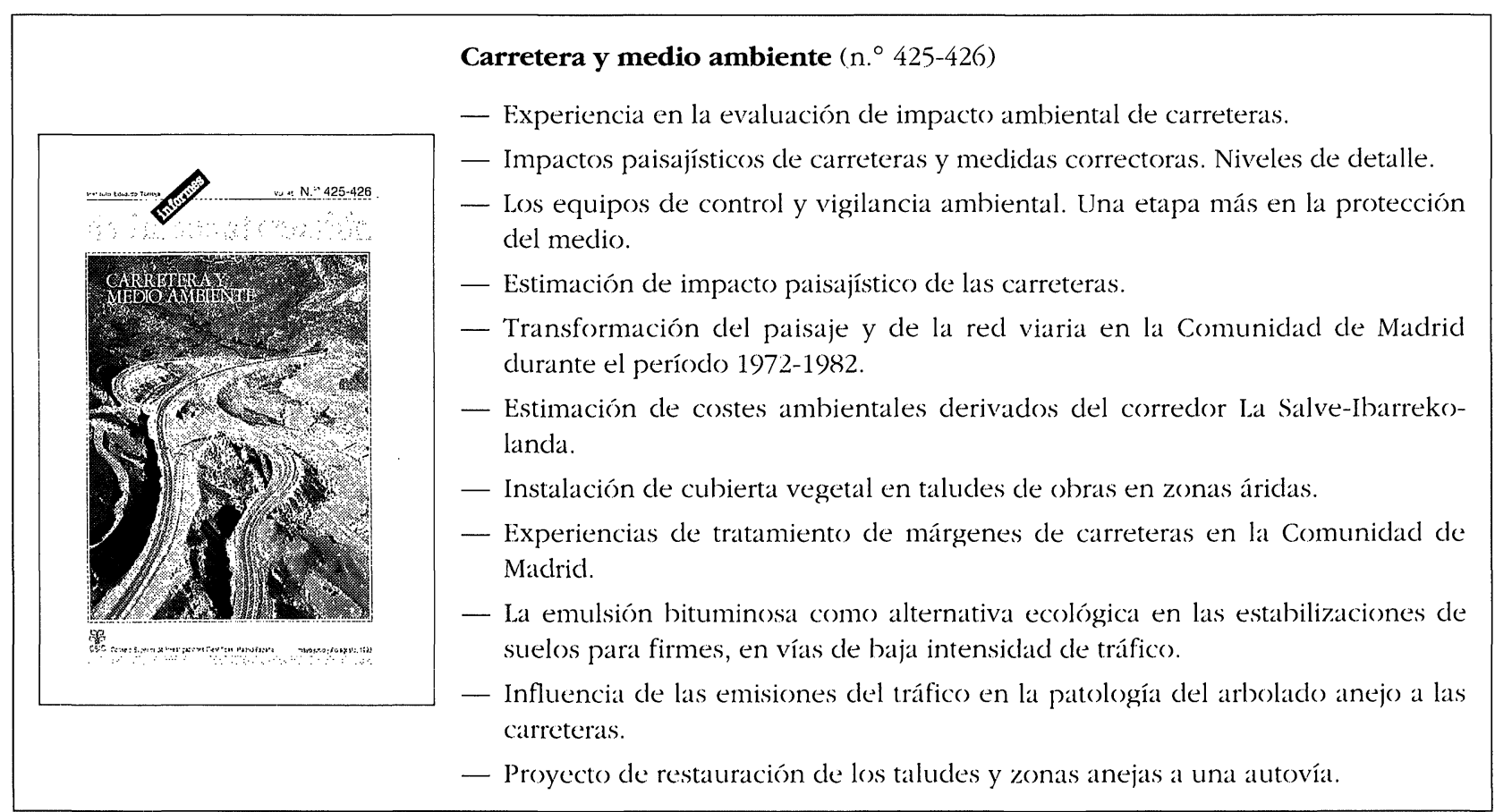

